Docomber 1, 1956

\title{
Prograss Report No. 22 Under Contract SC-5
}

From the Department of Chomistry of the University of Now Biexico

A. Moxxis Eiland and Milton Kahra

\section{CHEMICAI BFHAVIOR OF IODINE AI TRACER CONCENIRATIONS}

The study of methods by wh1ch the non-1odate component of the "Z" Iraction" is prepared has been comploted. The next phase of this project wil1 be devoted to tho charactori = zation of the non-10date component of the " $\mathrm{Z}^{\text {" Iraction. }}$

It is of primaxy importunce to determino whother or not the non-1odate component of tho " $\mathrm{Z}^{n}$ fraction exists as a radilo collold. According to Schubert2 zad1ocollolds can be distin= guished from true lonic species in solution by studying the effect of electrolyte concentration on the equilibrium distref. bution of the substance in question between an ion-exchange resin anc. tho solution. In general the amount of a trve lonj.c species on a resin will decrease with increase in electrolyte concentreition; the adsorption of a radiocoljold w1.13. remein essontially constant or incresse with increasing electrolyto concentration.

The anlon-exchange resin used in the following experiments was Dowex -1. which had been converted to the nitrate form and then equilibrated with 0.25 s。 nitric acid. In one series of experimonts carieler-\{roe lodine-131 vas oxid.ized over a pexiod of 24 hours by $0.50 \mathrm{f}$. nitric acld at $125^{\circ} \mathrm{C}$. The resulting solution was extrected ten times with $4-m i$. portions of benzene. This extrected solution, which served 8.3 a stocis solution of Iodine 131 , was found to have the following composition:

I-131 extracted by benzene

I-I3I. extracted by benzeno containing carrier $I_{2}$

I-131. in the form of 1odate

$I=131$ in the form of non-1odate " $\mathrm{Z}$ "

I-I3I lost during the analysis
$23 \%$

$10 \%$

I7 \%

$51 \%$

11. $\%$

Fach solution represented in Table 1 was propared by diluting one m.l. of tho stock solution to $8.0 \mathrm{ml}$. using such quantitios of redistilied water and nitric acld that the final nitric acio. concentreation was 0.25 fo Tho solutions wore sealod in "Pyrex" glass tubos and. rotated for 10 hours in a $25^{\circ} \mathrm{C}$, water bath. The results of these experiments are shown in Tablo 1. 


\section{DISCLAIMER}

This report was prepared as an account of work sponsored by an agency of the United States Government. Neither the United States Government nor any agency Thereof, nor any of their employees, makes any warranty, express or implied, or assumes any legal liability or responsibility for the accuracy, completeness, or usefulness of any information, apparatus, product, or process disclosed, or represents that its use would not infringe privately owned rights. Reference herein to any specific commercial product, process, or service by trade name, trademark, manufacturer, or otherwise does not necessarily constitute or imply its endorsement, recommendation, or favoring by the United States Government or any agency thereof. The views and opinions of authors expressed herein do not necessarily state or reflect those of the United States Government or any agency thereof. 


\section{DISCLAIMER}

Portions of this document may be illegible in electronic image products. Images are produced from the best available original document. 
$\operatorname{Tab} 101$

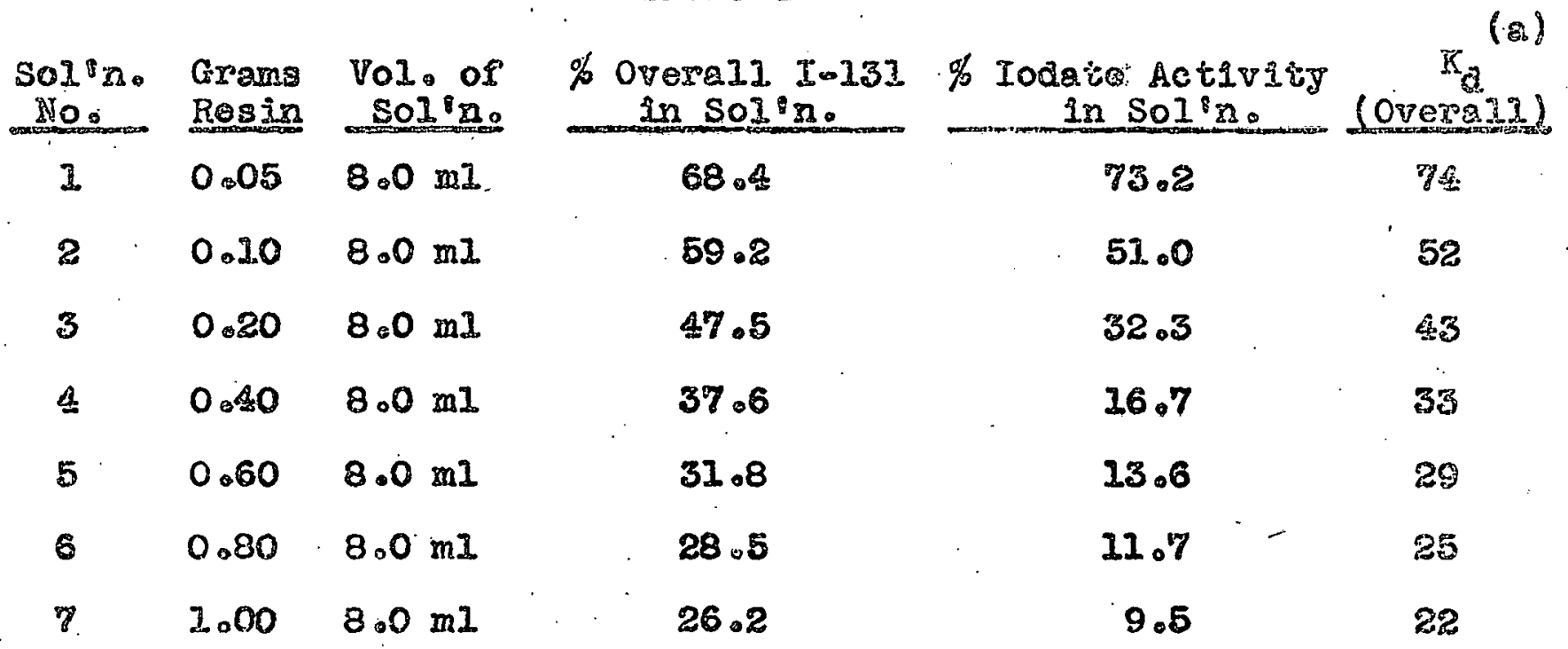

(a) The distribution coepficlent, $\mathbb{K}_{a s}$ is derined as

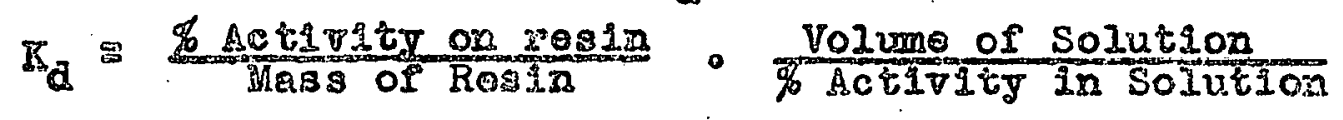

For tho adsorption of a true ionic spocies prosont in carriers

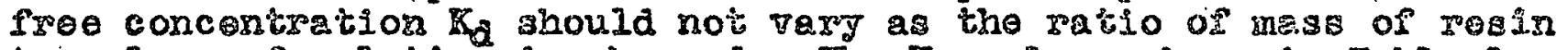
to volune of solution is changea. The $\mathrm{K}$ a values showa in Table 1 ropresent the adsorption of all tho lodine spocios prosent in the stock solution.

In another series of experiments the solutions represented in Table 2 were prepared. These solutions were simflar to those repree sented in Tabje 1 except that different amounts or potassium nItrato were addod to the various solutions and a different stock iodineal3! solution was used in their preparation. The composition or this stock iodine-131 solution was found to be

$\begin{array}{ll}\text { I-131 extracted by benzene } & 23 \% \\ \text { I-131 extrected by benzene containing } & 10 \% \\ \text { carmier } I_{2} & 20 \% \\ \text { I-13I in the form of iodate the form of non-10date "Z" } & 35 \% \\ \text { I-131 Iost durine the analysis } & 12 \%\end{array}$

The solutions were sealed in "Pyrez" glass tubes and roteted Por 10 hours in a $25^{\circ} \mathrm{C}$. water bath. The results of those experiments are shown in Table 2 . An analysis of these solvitons arcer equilibration with the resin made posalbio the calculation of individual $\mathrm{K}_{d}$ values $f \circ r$ the edsorption of iodate and for tho adsorption of the non-1odato component of the " $Z$ " fraction. 


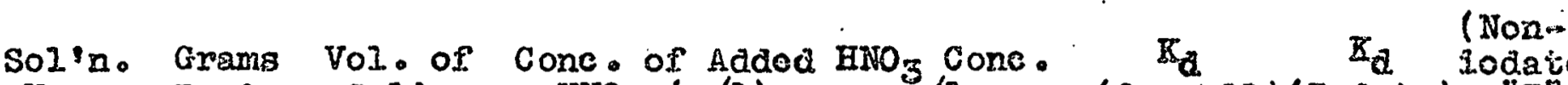

\begin{tabular}{|c|c|c|c|c|c|c|c|}
\hline $\begin{array}{l}301 \% \\
\text { NO. }\end{array}$ & $\begin{array}{l}\text { Grams } \\
\text { Resin }\end{array}$ & $\begin{array}{l}\text { volo ot } \\
\text { solin. }\end{array}$ & $\begin{array}{l}\text { Cone of Added } \\
\mathrm{KNO}_{3}(\mathrm{~m} / \mathrm{l})\end{array}$ & $\begin{array}{c}\mathrm{HNO}_{5} \text { Cone. } \\
\text { in/1 }\end{array}$ & (overeli) & Codate) & $\begin{array}{r}\text { Iodait } \\
1 \mathrm{Z}^{\mathrm{B}} \\
\end{array}$ \\
\hline 1 & 0.10 & $8.0 \mathrm{~m} 1$ & 0.25 & 0.25 & 78 & 64 & 30 \\
\hline 2 & 0.10 & $8.0 \mathrm{mI}$ & 0.75 & 0.25 & 78 & 59 & 32 \\
\hline 3 & 0.10 & $8.0 \mathrm{ml}$ & 1.25 & 0.25 & 75 & 58 & 33 \\
\hline 4 & 0.10 & $8.0 \mathrm{ml}$ & 1.75 & 0.25 & 76 & 60 & 34 \\
\hline
\end{tabular}

In a third serles of exporiments the solutions represented in Table 3 were preperod. Those solutions wore also similar to those represented in Table 1 excopt that in this instance different amounts of phosphoric aeid were added to the various solurions. The stoek iodine-i3I solution usod in proparing those solutions fras found to have the following composition:

In-13I oxtracted by benzene

I-13I extracted by bonzeno containing carrier $I_{2}$

$I-13 I$ in the form or lodate

- I-.23I in the form of non-iodate " $\mathrm{Zn}$

I-131 lost during analys is
$13 \%$

$8 \not 6$.

$44 \%$

$35 \%$

$0 \%$

The solutions wore sealed in "Pyrox" glass tubss and rotated for 11 hours in a $25^{\circ} \mathrm{C}$. watior bath. The results of these experiments are shown in Table 3. The presence of phosphate in the resction solu. tions interfored with the lodate anglysis and provented the calculetion of $K_{f}$ values for the adsorption of the individual Iraction present in the solutions.

Table 3

\begin{tabular}{|c|c|c|c|c|c|}
\hline $\begin{array}{l}\text { Sol'n. } \\
\text { Noo. }\end{array}$ & $\begin{array}{l}\text { Grams } \\
\text { Resin }\end{array}$ & $\begin{array}{l}\text { Vol of } \\
\text { Soling }\end{array}$ & 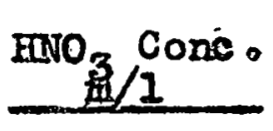 & $\begin{array}{c}\mathrm{H}_{3} \mathrm{PO}_{\frac{4}{\mathrm{~m}}} \text { Cone。 } \\
\end{array}$ & $\begin{array}{c}\mathrm{K}_{\mathrm{R}} \\
\text { (Overe11) }\end{array}$ \\
\hline 1 & 0.10 & $8.0 \mathrm{ml}$ & 0.25 & 0.10 & 69 \\
\hline 2 & 0.10 & $8.0 \mathrm{mI}$ & 0.25 & 0.50 & 98 \\
\hline 3 & 0.10 & $8.0 \mathrm{mI}$ & 0.25 & 1.00 & 96 \\
\hline 4 & 0.10 & $8.0 \mathrm{ml}$ & 0.25 & 1.50 & 100 \\
\hline
\end{tabular}

The work with lon-exchange resins is being continued. Fur ther adsorption experiments will be carried out is ing a cation-exchange resin hoving physical characterisics similar to those of the aniono exchange resin usod in the above experingents. 
NOTES:

1. The "Z" Iraction 1 s derined as lodine activity which is not extracted from aqueous solution by benzene or by benzeno containing carrier iodine $\left(I_{2}\right)_{0}$

2. Schubert, Jo, and Richtor, J.W, J. Collold Sciene, S. $376-385(1950)$.

3. Whe various Pretions and the 1 analysis are discussed In Progress Report No. 19, p. 3, dated March 1, 1956.

B. Katherya Lamaon and. Hilton Kahn

BEHAVIOR OF INDIUM AT TRACER CONCENTRATIONS

The study of the adsorption of Indiuml15 from aqueous solution was continued. Exporimonts doscribing the adsorption as a function of timo, pH, suriace material, lonie strength, and olectrolytes havo boon conducted.

\section{Experimenta1. Procoduro and Resulits}

I. Adsorption of Indium by Pyrax - Effect of Differant Elocirolyiss.

Tho adsorption of carrier-free indiun-115 onto the walls of the Byres reaction vessel was determined for varying values of pH and in the presence of different eloctrolytes. The temperature and ionic strength of the solutions were hold constant. The solutions wero proparod by adding indium activity in $0.105 \mathrm{M}$ perchloric acid to onough ammonium hydroxide and electrolyto solution to give an ionic strength of 0.34 and the desired $\mathrm{pH}$. The solutions were 2110 wed to stand in the serled reaction vessel for ten minutes at $32.2^{\circ} \mathrm{C}_{8}$ rotated fos thisty minutes, then contrifuged for ten minutos. The percentage indium adsorbod onto tho Pyrax walls mas determined from the loss of activity in the supernatant liquid. Tho offocts of four different ammonium salts on the adsorption of indium are shown in Figures 1 . 4

II. Adsorption of Indium - Effect of Surface Metorial:

Four types of reaction vose els - (quarti, Pyrex, polyethyleno, and pasafin-coated Pyrox) - were used to study the extent of adsorption as a function of surface materilal. The vosBols were 8.11 $15 \mathrm{ml}$. centrifuge tubes which were not soliod off aitor introdue tion of the solution. The solutions were agliated and protected fron tho

Described in Progress Report No. 21. $227 \quad 00 \%$ 
5.

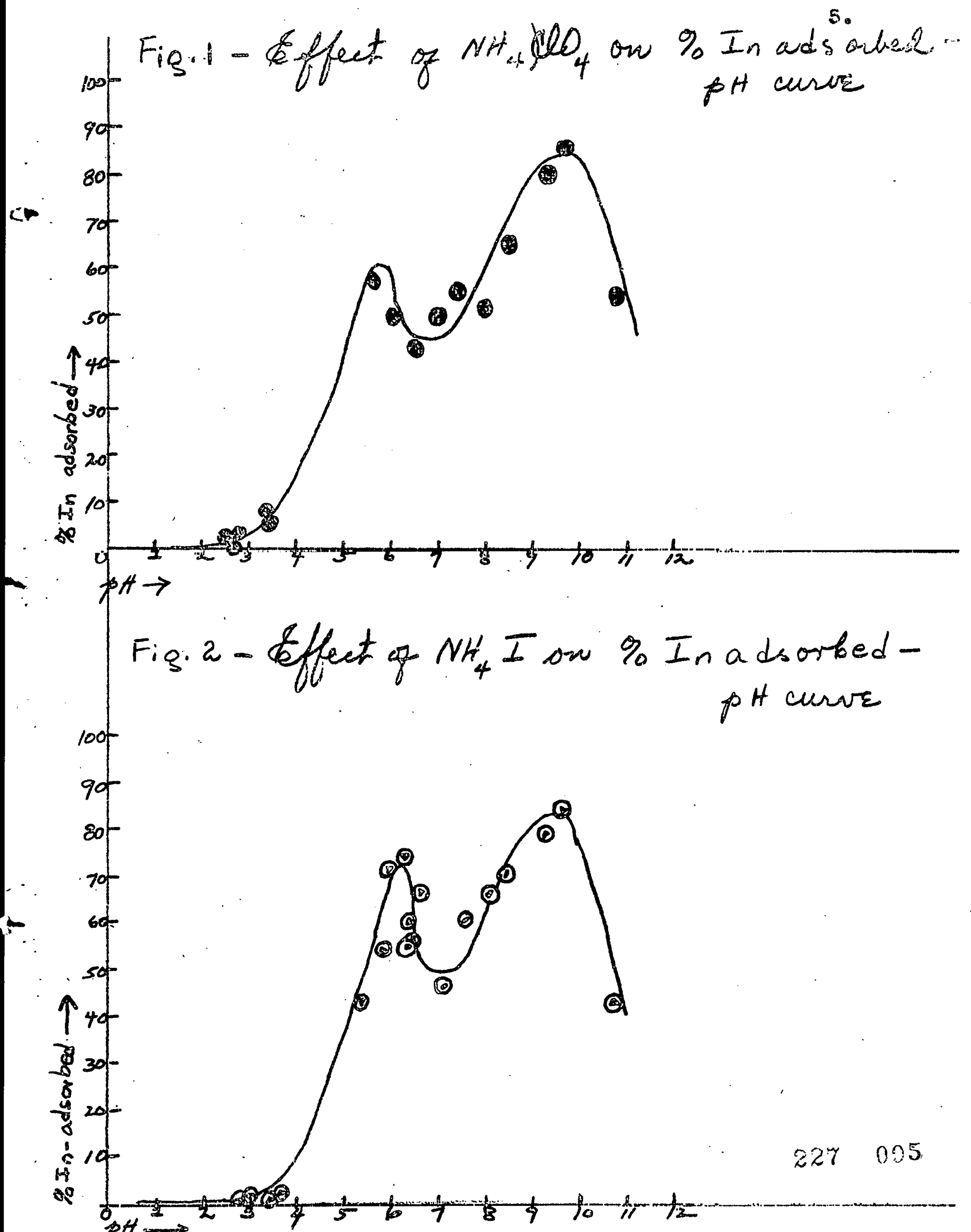




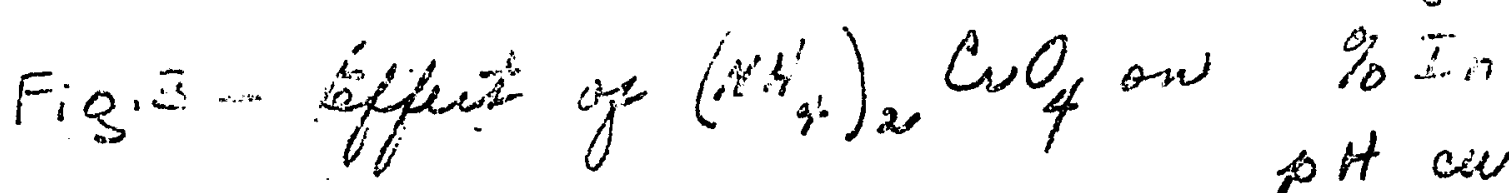
pit cinde.

Fig. 4-Eeffect of $\left(\mathrm{NH}_{4}\right)_{2} 1+\mathrm{PO}_{4}$ an $\%$ In adsoubed -ptt curir

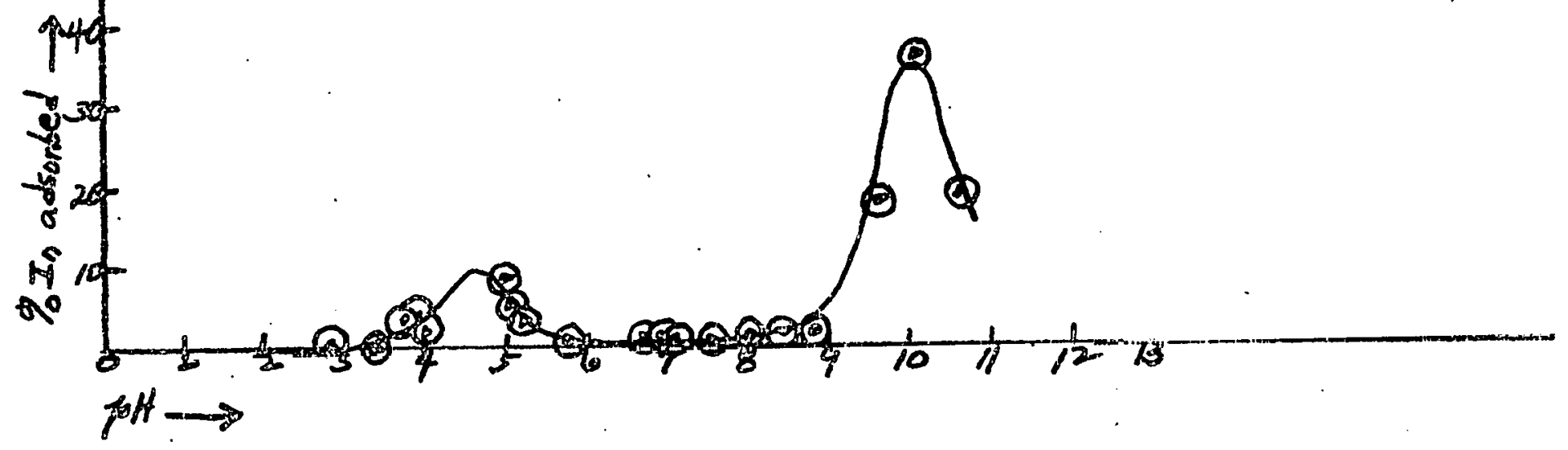

$227 \quad 006$ 
a tmospiasx by bubbling a siream of $\mathrm{g}_{2}$ through for the duration of the reaction time. The $N_{2}$ was previousl. a aturated with water vapor at the seme temperature of tho experimento $\left(32.2^{\circ} \mathrm{C}\right)$. Ali solutions were held at an ionle sirength of 0 izA and tho added electrolyte was ammonium chromate, $\left(\mathrm{MH}_{4}\right)_{2} \mathrm{CmO}_{4}$. The results are show in Figures 5 - 8 o The adsorptioñ on quiarte and Pyrox 1a ossentialiy the samo.

III. Adsorption of Indium on Quartz - Effect of Ionic Streneth and Time of Contact:

The effects of lonic strength and time of contact on the adsorption of indium by quartz were studied. Aqueous solutions of sulteblo pH wor obtalned by mixing perchlorio ac1d solutions of the indium activity with ommonium bydroxide and, in the case of the higher Ionje sirength, ammonium perchlorato. The experimental procedure was similer to thet described under the adsorption of Indiun as a function of surface material. (Section II of this reportwo) The results are shown in Figures $9-13$.

The exporimental posults obtainod to dato shor tho eztent of adsorption of carrier-fro indium from aqusous solution under vasious conditions. In vesy dilute solutions, such es the ones used in these experiments, adsorption is generalis oither redios colloldal or by lon-exchange. Exporiments are nom being planned to investigate the mechanis of this adsorption. These experinents will include tests for revorsibility of tho adsorption process at various $p H$ values and roformation studies.

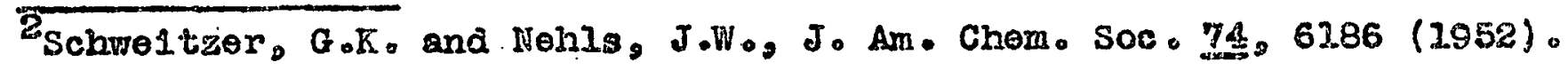




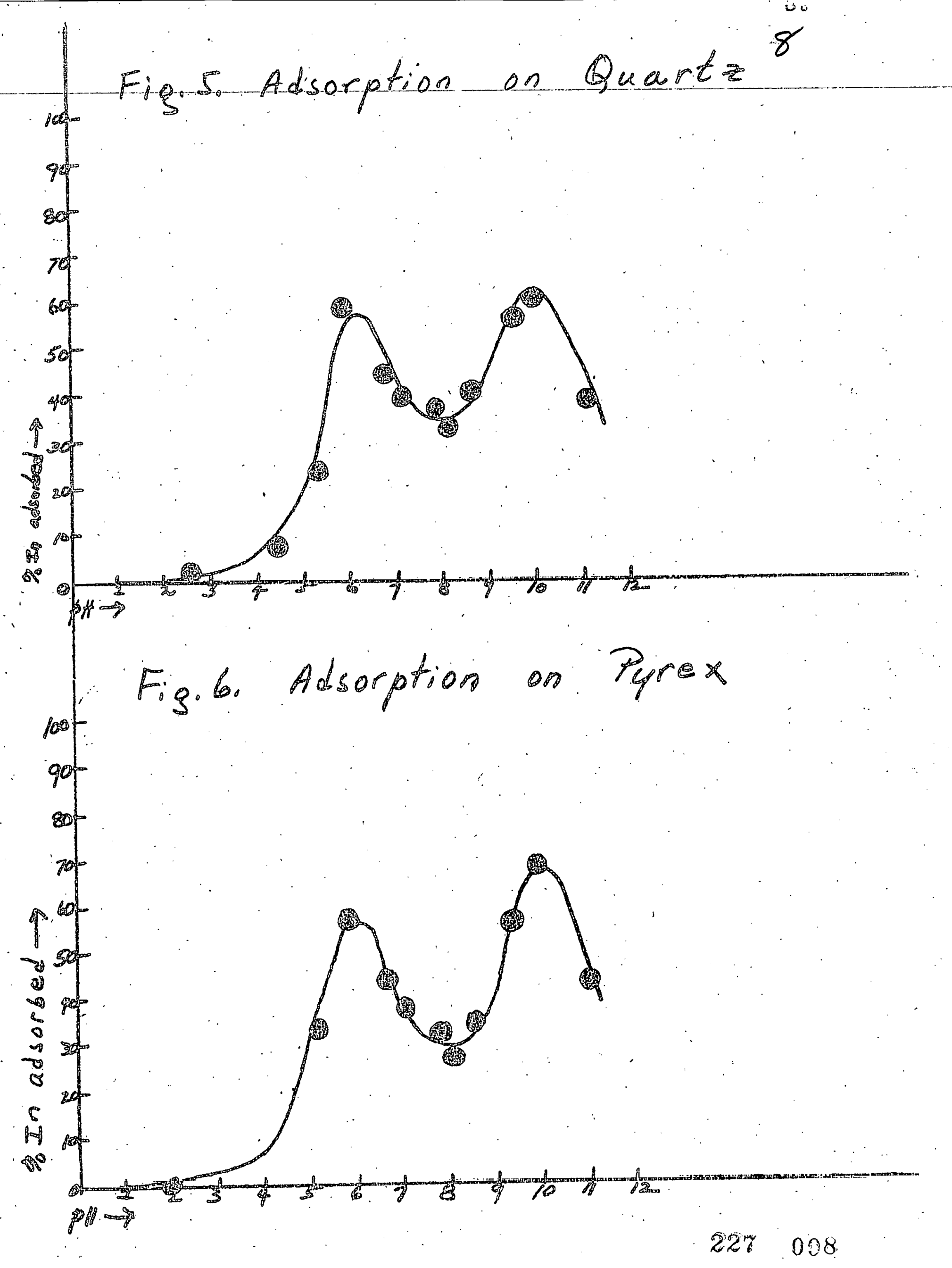


9

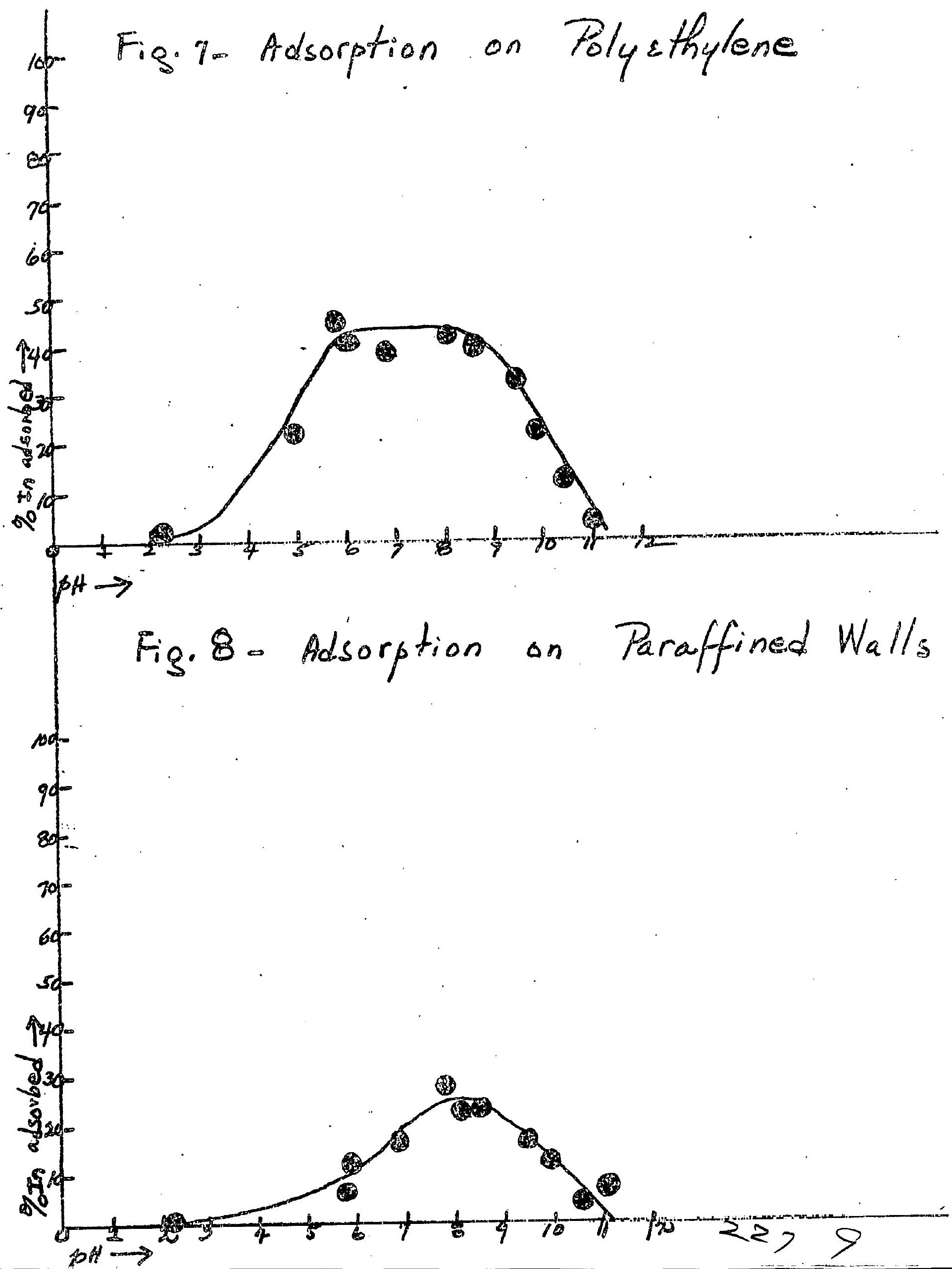


20.

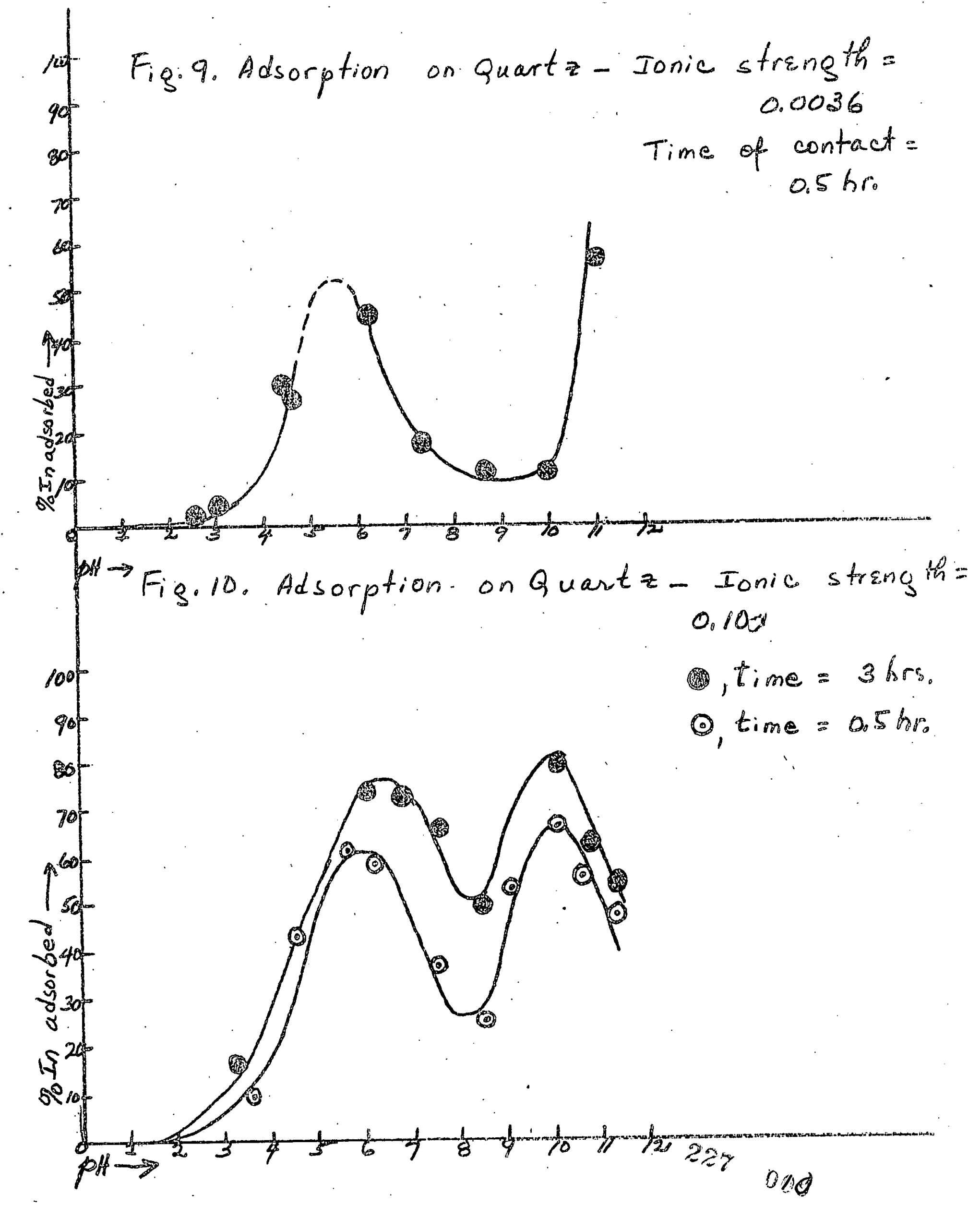


Fig.13.. Eeffest $q$ dime of Contact on adsonption of ondisins.

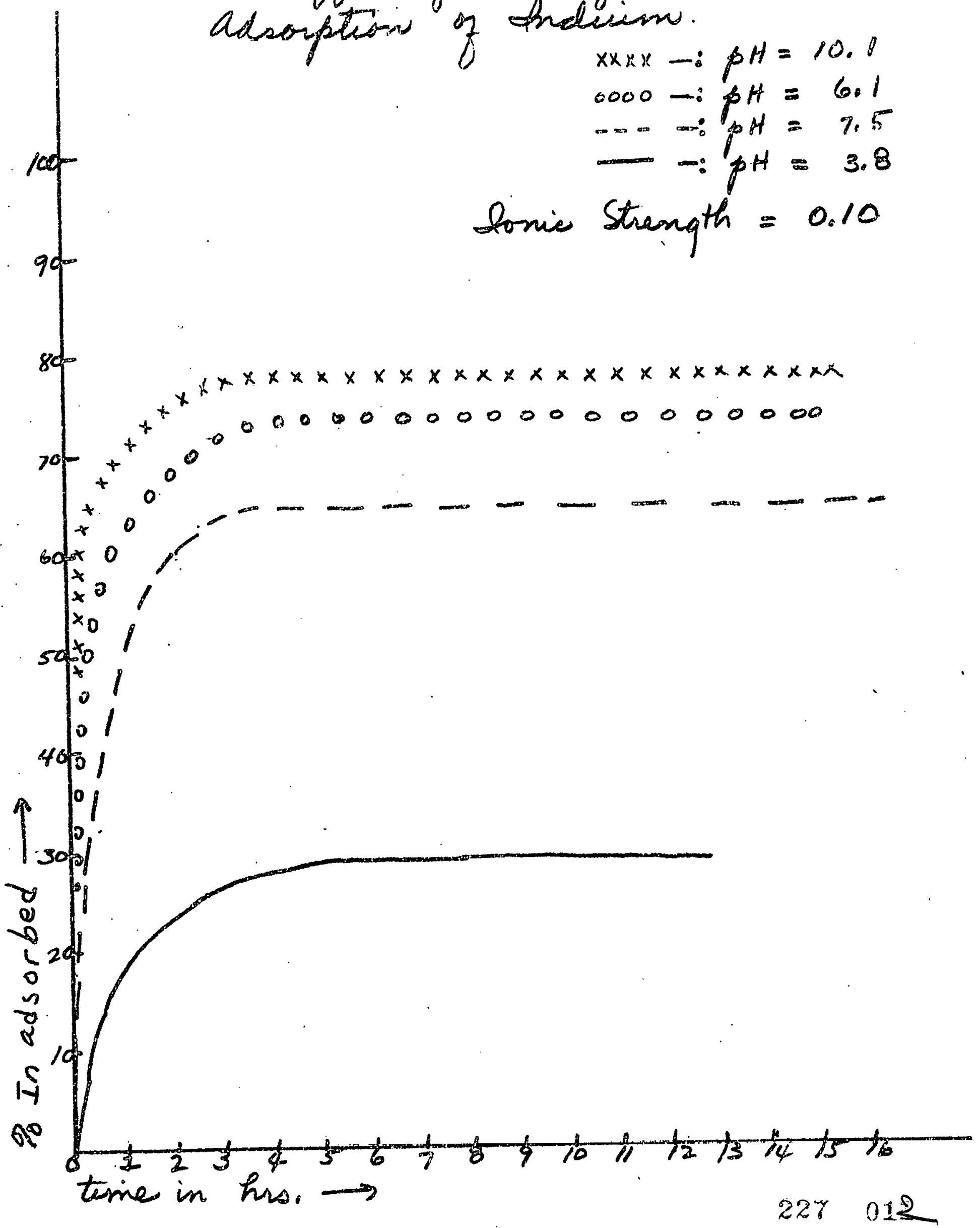


C. Mititon Kahn

IITERATURE SURVEY OF DIIUTION SOLUTION CHEMISTRY, "HOT ATOM" CLERISTRY, AND ISOTOPIC EXCHANCE REACTIONS

A Ifteraturo survoy of work, reported in Chomical Abstracts and Nucleas Science Abstracts fron 1950 to 1956 inclusive, involving dilute solution chemistry, "hot atom" chemistry and isotopic archenge reactions is in progress.

D. R.E. Panzer and J.F. Suttze

PREPARATION AND PROYERTIES OF SORE URANIUM-PHOSPHORUS CHLORIDES

\section{Introduct1ox}

The invertigations on this top 10 this pest quester have taken several trends. Hothods of analysis of these materials were improved, ospocially the method for phosphorus. Hethods of preparation of these UCI ${ }_{5}$. $\mathrm{PCI}_{5}$ complexes were improred。 Also injtiated this quaster mero golvenic extraction studier directed torard the separetion of UCI and PCI give a puxs UCI produst. Anothor phase of the rosearch concerned the posaiblo formation of $\mathrm{O}\left(\mathrm{OC}_{2} \mathrm{H}_{5}\right)_{5}$ by reaction of these complexs witib sodium othoxide, acotaldehyde ox other sultable roagent.

\section{Experimental}

A. Anglytical

In provious analyses somo trouble had been experioncea by proclptitition of the excess uxanium when a urany phosphate procedure vas used to determine phosphoms. To eliminate this difficulty a different mothod of phosphomes analysis was applied. This method Involves tho uaval procedure of precipitation of the phosphorus as amonium phospho-molybalate, fil.tration of the yollow precipitate. washing with $5 \%$ ammonilam $n 1$ trato and ignition at $400-450^{\circ} \mathrm{C}$. to the final weighing form $\mathrm{P}_{20} \mathrm{O}_{5}$ ' 24M $10 \mathrm{O}_{3}$. The singuler advantages. of this procoduro aro its repidlty aid the hlgh molocular woight of tho wolghing form, giving low gravimetric iactor. Application of this mothod to analysis of the complexss undor study has given consistently good resulis with a minimam of timo and manlpulation:

\section{B. Preparation of complexoa}

Somo orango complex, UCI $5 \mathrm{PCI}_{5}$ was gradually hoated to $200^{\circ} \mathrm{C}$. With a change in colos to green taking place. Chlorine Was given off. Anelysis of the resulting product showed it to bo eseontlally $\mathrm{UCI}_{4} \cdot \mathrm{PCI}_{5}$. LittI. or no sublimation of the PCIs was observed. 
In another exporinent a yellow and an orenge product were obtainod in tho same reaction mixiure whon using $\mathrm{POCl}_{3}$ to dissolve the product. These two meterials were found to differ 11 ttio in composition. The jollow product: had a slight excess of $\mathrm{ECI}_{5}$ present over the calculated amount, but no other differonce. Furthor work is to bo dono on this phase of investigation.

C. SoIvent Studies of the solubility of UC1.5 2 2PCI

Proliminary work with certain selected solvents aiscioner that some of them might be useful in separating UCI 5 from the $\mathrm{PCI}_{5}$. It was found that $\mathrm{PCI}_{5}$ was increasingly solublo in the serles benzene, toluene, xylene (the natural mixture of xylene iscmers). In the same solvents the complex was silgitily solublo, solubility increasing in the ame order, but much recuced in magnitudo. This has a direct connoction vilu tho stability of this complox as w11l be notod later. Other solvents used included petroleum ethor (B.P. $30-60^{\circ} \mathrm{C}$ ), 1,4

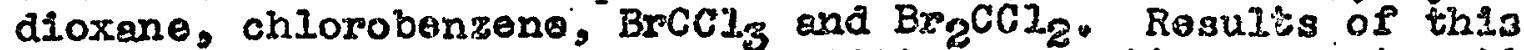
work are shown in Table I. In addition, continuous extraction of the complex was carried out using toluene and sylene in a Soxhlet extraction apparatus. A portion of previously analysod complex was plaved in the fritted coarso glass filter tubo which was pleced in tho extraction apparatus.

Table I

Solubliltios in mg/ml

\begin{tabular}{|c|c|c|c|c|c|}
\hline Solvent & UC215 & $\mathrm{PCI}_{5}$ & PCI5 alone & Notos & \\
\hline Benzeno & .187 & 1.81 & 63.7 & & \\
\hline Tolueno & .093 & 1.96 & 67.8 & & \\
\hline Xylene & .093 & 2.90 & 73.3 & & \\
\hline $\begin{array}{l}\text { Petroleum } \\
\text { othor }\end{array}$ & none & 4.017 & 21.1 & & \\
\hline $1,4 D \operatorname{Loxan} \theta$ & 1.15 & 3.07 & Reacts & rapidIy with $\mathrm{PCI}_{5}$ & $\operatorname{siche}$ \\
\hline Chlorobenzeno & .120 & 2.98 & 65.5 & & \\
\hline $\mathrm{BrCC}_{33}$ & .094 & 3.31 & not dons & & \\
\hline $\mathrm{Br}_{2}{ }^{\mathrm{CCI}} \mathrm{z}$ & .70 & 3.07 & not done & & \\
\hline
\end{tabular}


Aster roluxing fox 24 hours with the golvent solocted, the complez vias freed of solvent by ovecustion and then ansiyzed. Whon the toluene ras used the solvont passing through tho complex always maintalned yollowish tingo, whereas, with the xylone this coloration eventuaj.lJ clearod. In Table II ere shown the results of the analysis of tho comploz beforo and after extraction.

\section{Table II}

Compleas

Before

Ixtraction

29.25

37.3

5.00

37.3 蜎

After

Tolueno

Aftex xyleno

4.94

U-\% Incroase P-\% docrease

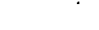

27.5

35.7 .

These flgrares indicate that thera is an enplehment of the come plex rolative to the uranium content. Mnls enrolebnent 13 not quite as much as might be oxpected. Furthoxmoze, the Iinal figures for the 8 and $P$ content in both pojtions of the compless after extraction with oither solvent are neax'ly the senne as the percentage of these olements in the complex UCI5 ${ }_{5}$ PC25. This indicates thet the $0 \mathrm{Ctx}^{\mathrm{P}} \mathrm{PCI}_{5}$ in the original complex (whose

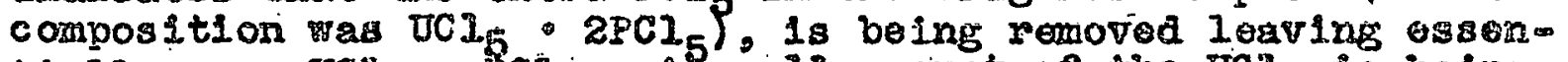
tialiy pure UCI. $\mathrm{PCI}_{5}$. $A$ small amount of the $\mathrm{UCI}_{5}$ is being extrsactod in the proaess. Further investigation on this tople is to be carsted ouli using other solvents and portions of a mono-complex UCI 5 - $\mathrm{PCl}_{5} 5^{\circ}$

D. Formation of Uranium (V) Ethoxide and related compounda. The work of Gllmen et $0.20^{2}$ concerming the preparation of $U^{i}$ othoxide was reviowed in tho literature as possiblo means of separation of the uranitum in the present research.

The filman group had used several reactions based chleily. on the rollowing:

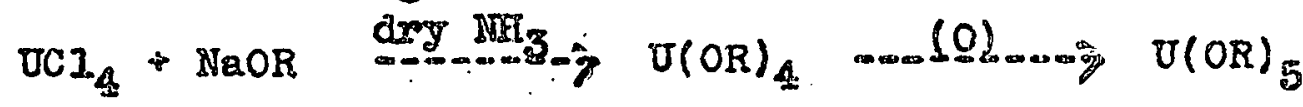

and

$\mathrm{UCI}_{5}+5 \mathrm{ROH}+5 \mathrm{HE}_{3}(\mathrm{dry})----9 \mathrm{~V}(\mathrm{OR})_{5}+5 \mathrm{NH}_{4} \mathrm{CI}$

Although these reactions are of interest in the present works the use of an alcohol with the complexes results in tho formation of water with 1 tgattendent roaction with $\nabla^{V}$ comor pounds to reduce them to UIV. It is possible that the reaction of UCI ${ }_{5} \cdot$ PCI $_{5}$ With a sodium alkoxjde may give a definite separable product. This reaction will be applied during the next quarter. 
Another reaction of possiblo use in this line of reserseh is that betwoen acotaldehyde and UCI5: PC15. In this case the products to bo expected are not entirely known. However, one peaction of these meterials resulted in a dark brown solid product. This naterial is Insoluble and unchanged in weter? soluble in acotono and other organic solvents, such as chlorinated hydrocarbons. Anelysis on the "as produced" material shows the presence of $41.3 \%$ Und $28.2 \% \mathrm{P}$. Purlflcetion and characicr. ization of this material are incomplete at this timo. It is signiflcant that the reaction produced largo quantitios of ECI and was exothermic. It was expocted that the product would bo dark brown, since tho $V^{V}$ ethoside is a bromn liquid, distiliablo under reduced pressure of 1 micron at $123^{\circ} \mathrm{C}$. Further investigation of this seaction seoms justifiod.

III. Conclusion

A notable fact hes made itself ovident in the results of this research to date. That is the'stability of the complox UC1 5 : PCI compared WIth UCI5 alono This Iact Ls demonatrated by $(i)$ the ract thet tho complex may bo heated to ebout $150^{\circ} \mathrm{C}$ without chasge; (2) the complex may bo treated with aolvents at olevated temperatures with 11 titie or no change; (3) solvents in which PCI $I_{5}$ 1.s quito soluble have 11tile effect on the complax ox the PCI5 thareln; (4) PCI 5 does not sublime away from the comm plex without use of comperativeiy high tomperatures: (5) the UC1 $2_{5}$ portion of the comploz does not seom to decompose except at rathox high temporetureso

By ray of comparison, the allman group claing that UCls decomposes spontanously at room temperature to givo UCI 4 and C1. This stability of tho complex appears to be quito unlana by comparison with other uranium (V) compounds.

REFLRENCES:

1. I.M. KoIthoff and E.B. SandolI - TEXTBOOK OF EUANTITA... IIVE ANALYSIS (I9A8)。

2. GiIman, Ho ot al. J.H.C.S. 78; 4285, 4287, 4289; Sept. 5. 1956 。

E. Milton Kahn and J.I. Riebsomer

THE EXCHANGE REACTION BFTWEEN SUBSTITUTED

BENZYL IODIDE'S AND POTASSIUMI IODIDE

One more menuscript has been propared in this serles and will be sent in for publicetion simultaneously with this roport. 
F. John Coljzer and J.I. Rlebsomer

\section{SYNTHESIS OF OXAZOLES}

In the aitoinptod preparation of 2-a1othylaminoethyl5-ethyl-i-phengloxazole, by cyclization of the keto-oster $(x)$ with ammonium acetate and acet1c acid, the chlorine atom $x$ Iost.<smiles>CCCCCC(=O)OC(CC)C(=O)c1ccccc1</smiles>

I

Compound I was thon rerluxed with two oquivalents of diethylamine in absolute thanol for thirty minutes in order to replece the ehlorine atom with a diethylamino group before cyclization. The HCI produced in the reaction is taken up by the axcess diethylamine. Tho solvent fras removed under reduced pressure and dry ether was added to the residue. The insoluble crystalline material was filtered of and driod. This matorial meltod at 216 ar170 (diethylamino hydrochlorido is repoxited to melt at $228-229^{\circ}$ ). (sixty-flvo percent of the thooretical amount of the diethylamino hydrochlorido was obtained.

The illtxate remaining after removal of the diethylamino hydrochloride pas dried over anhydrous sodium sulfato, and the solvent removed under reduced pressure. The residue vas then distilled under reduced pressure. The distillate was collected from $80-105^{\circ}$ at $0.5 \mathrm{~mm}$.

A portion of tho distillato wes dissolvod in dry ethor and dry HCI was bubbled through tho solution. An of separatial immedietely, which, after some difflculty, crystaliized from an alcohol-ether mixturo. Infs material melted at $137-138^{\circ}$.

An analyticel sample of this material (II) was prepared and analyzed for carbon, hydrogen and nitrogen.

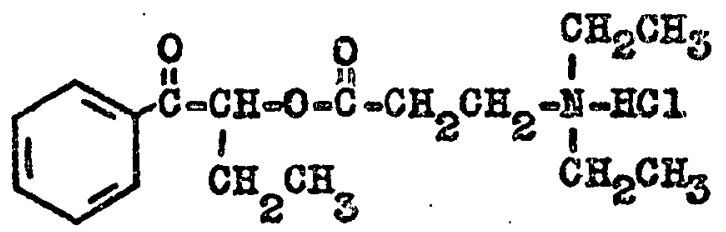

$I I$ 
The results of the analyses were:

$$
\begin{aligned}
& \text { \& caxbon: calc., 62.28; found, } 58.65 \\
& \text { \% hydrogen: calc., } 7.99 \text {; found, } 7.46 \\
& \text { \% nitrogen: calc., } 4.27 \text {; found, } 4.99 \text { and } 5.15
\end{aligned}
$$

These analytical rosults seom to indicate that compound II wo.s not obtained. Whether this is due to impurities not yet removed from compound II or due to tho formation of an un known compound during the synthesis is not at this moment ascertainable.

Another portion of the distiliate (the free base of II) was dissolved in absolute ethanol and warmed with a saturatod solution of pleric acid in ethanol. Upon concentration of the solution and cooling, an oll separated. All attempts to cause this oll to crystallize fallod.

G. C.G. Warren and John F. Suttlo

$$
\text { SOLVENT EXTRACTION STUDIES }
$$

I. Introduction

The alkyl diasid phosphater were cryetallized by dosiccstion. The distributions of the various components of a system composing nitric acid, butyl phosphete, lenthanum nitrate noodymium nitrato, amyl alcohol, and water wero dotormined.

II. Experimental

The elky 1 diacid phosphates were crystallized by the following procedure. The ester was extracted from the water with ether. The ether evaporeted at room temperature in about 24 hours. The romalning wator was removed, over silica gel, in about seven deye. The ester was cooled in the refrigerator and a small amount was frozen with liquid nitrogen. In several hours all of the ester was crystall1zed. A weighed sample of the crystals was titrated with sodium hydroxide solution with methyl red as an indicator. The titrations indicated the molecular woights given in Tablo Io Various phosphato analys as are now being investigated. The usual wet ashing reagents interfere with the subsequent determinatione.

Table I

$$
\underline{\mathrm{BuH}}_{2} \mathrm{PO}_{4} \quad \mathrm{AmH}_{2} \mathrm{PO}_{4} . \quad \mathrm{Oc}+\mathrm{H}_{2} \mathrm{PO}_{4}
$$

Theoretic al

Molecular Welehta

154.1

168.2

210.2

Experimental

Molocular Welgito

155

175

208

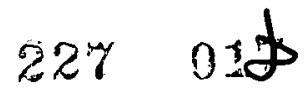


Distribution of the alkyl phosphates betweon water and ether was fnund to bo concentration depondent. The concentrations of the alkyl acid phosphatos wero determinod by titration. Tho concentration of the ester in moles per liter is given in Table II.

Tablo II

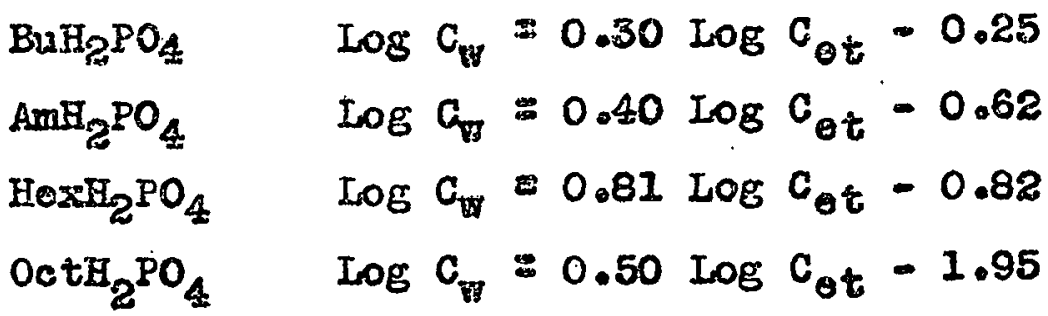

Since the distribution follows such a complicated pattern the use of ethor was discontinued.

Tho distribution of alkyl diac1d phospbato botwoen water and anjl alcohol follows a much simpier patiern. The distribut1on remains approximetely constant with different concentrations of tho phosphate ester. A plot of Log D $\left(D=\frac{C_{A m}}{C_{\mathrm{H}_{2} O} \mathrm{O}}\right)$

verses length of the carbon chain flelds approximato Is straight lino. It is of interest, that $R . C$. Archibala 1 published data on tho diatribution of tho fatty acids batwoen amyl alcohol and water. A plot of Iog $D$ verses length of the carbon chain jields approximately atraight IIno paraliel to the one for the phosphate esters. Flgure I gives this dota.

The acid concentrations in the system of amyl elcohol, weter, nitric acjd, and butjl diacid phosphato pere determined by titration with sodium hydroxide solution to $\mathrm{g} p$ of 4.5 and 9.5 . The flxgt end point, pH 4.5 , gives the sum of the two acid concentrations. From pH 4.5 to $\mathrm{pH} 9.5$ ikrs second acid eroup of butyl diacid phosphate is titrated. Analysis of the results of the two titrations give the conceniration of each acid.

The distribution coofficients, $D=\frac{C_{A m}}{C_{W}}$, of lanthanum and neodymium nitacates in the above system vere determined by radiochemical tachniques. Date from both of these methods aso given in Table III. 
Figure 1. The distribution of Organic acids betweer amyl alcohol and water.

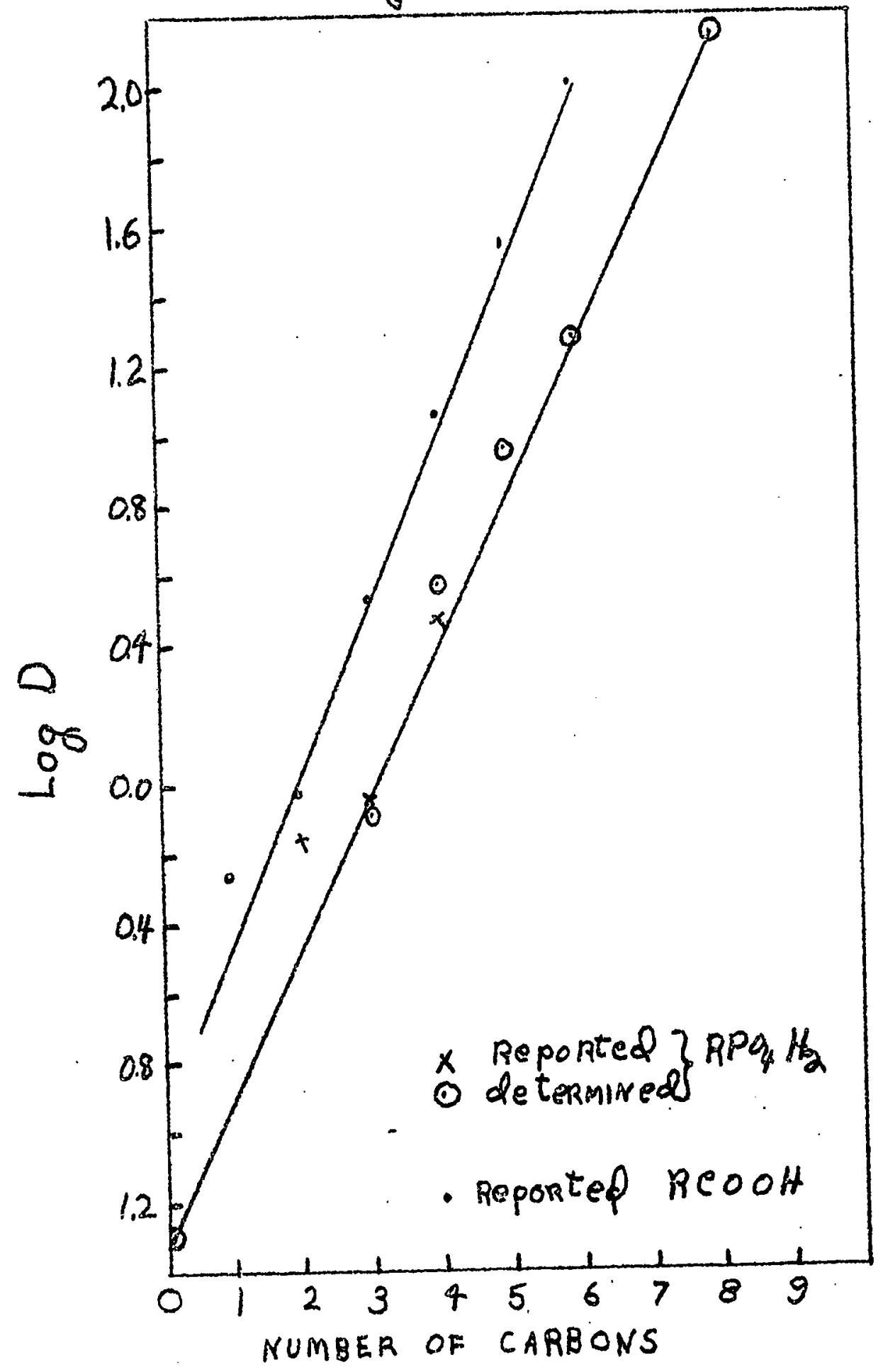




\section{Tehie III}

The partstion of lantinanum, noodymium, nizic acid and butyl diacid phospheto botweon water and amyl alcohol. The concontretions are in molos per liter. The D's aro dimensionless.

\begin{tabular}{|c|c|c|c|c|c|}
\hline \multirow{2}{*}{$D_{L a z}$} & \multirow{2}{*}{$D_{\text {MR }}$} & \multicolumn{2}{|c|}{ Wa tere. } & \multicolumn{2}{|c|}{ ÁnOF } \\
\hline & & $\mathrm{C}_{\text {EnTO }}$ & $\mathrm{C}_{\mathrm{BuH}_{2}} \mathrm{PO}_{4}$ & $\mathrm{C}_{\mathrm{HNO}_{3}}$ & $\mathrm{C}_{\mathrm{Bur}} \mathrm{BO}_{\mathrm{S}}$ \\
\hline $\begin{array}{l}1.16 \\
0.067 \\
0.022 \\
0.011 \\
0.0093\end{array}$ & $\begin{array}{l}1.28 \\
0.34 \\
0.1 .4 \\
0.10 \\
0.077\end{array}$ & $\begin{array}{l}0.00 \\
0.114 \\
0.293 \\
0.550 \\
1.06\end{array}$ & $\begin{array}{l}0.0748 \\
0.0748 \\
0.0660 \\
0.0656 \\
0.0650\end{array}$ & $\begin{array}{l}0.00 \\
0.0 .04 \\
0.0495 \\
0.121 \\
0.321\end{array}$ & $\begin{array}{l}0.268 \\
0.268 \\
0.2771 \\
0.277 \\
0.275\end{array}$ \\
\hline $\begin{array}{l}0.30 \\
0.085 \\
0.031 \\
0.020\end{array}$ & $\begin{array}{l}0.44 \\
0.19 \\
0.11 \\
0.072\end{array}$ & $\begin{array}{l}0.142 \\
0.289 \\
0.563 \\
1.04 .\end{array}$ & $\begin{array}{l}0.140 \\
0.132 \\
0.122 \\
0.119\end{array}$ & $\begin{array}{l}0 . .0 \\
0.047 \\
0.130 \\
0.330\end{array}$ & $\begin{array}{l}0.520 \\
0.520 \\
0.527 \\
0.526\end{array}$ \\
\hline
\end{tabular}

* Due to the small concentration of HNO 3 tho determination was inaccurato.

It will be noied that the distributions of nitric acid and butyl dacid phosphate are almost Independent of eaeh othex. WI th this simplifying assumpion the distribution of nitric acid is as follows:

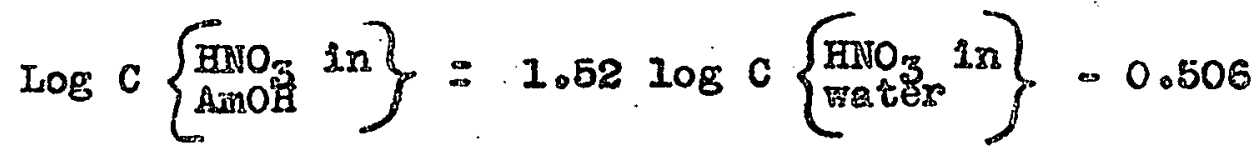

REF I.RENCES:

1. Archibald; R.C., J.A.C.S。 54, 3178-85 (1932)。 
H. J.F. Stampfor, Chasles Holley, and Jos. SuttId

THE MAGNESIUR OEYDROGEN SYSTEM

As alffusion of hydrogen from tho pressure reactors being used has caused so much trouble, the retos of diffusion from the vasious sections of tho reactor wore crudely detere minod. Thls was accomplishod by fabricating the varioun piedes of the reacior and wolding oach one to an inlet tube. They were then suspendod, one at a timo, In the fumace so thet the meld was at a sufficlontly log tomporature that diffusion mould not take place through it. Hydrogen was then adnittod and the decrease in prosisue at constant temperature noted.

By assuming that at the temperatures and prossures unders study the diffusion is inversely proportional to the wall thlek. noss a new reactor was bullt. This reactor should havo. shown a nogligible rate of diffusion. The design was es Rollows. The body was fabricated from a $3 \frac{1}{5^{n}}$ long by $2^{n} 0 . D$. rod with a $23 / 4^{n}$ long by ${ }^{n}$ bose. The neck is a $2^{n}$ long $x$ lin $0 . D$ orod with a $\frac{1}{3}$ ir boro drillod through it. Theas two piecer wero weldod together. After loading wth magnesiurn, attachmont of the inlet tube mas offected by are-srolding whilo the body was cooled in IIquid nitrogen and the Interfor wes kopt under an Argor Atmosphoro.

Aftor a successful Iesk tost, tho reactor was pressurod with hydrogen and takes to $470^{\circ} \mathrm{C}$. At this tompsiature tho bydride. Is completely dissoelated. A loss in pressure at consiant temperatuxe mas noted which amounted to about $3 \%$ of the tois. bydrogen present per hour This loss was attributed to diffusion. There are at loast two possible reasons why the actual rate is so much greater than that originaliy calculated. A.) one of the wolds may havo an exceodingly thin spot which would a.low a relatively laxge amount of 88.3 to escape. B.) The assumption that the rate is inversely proportional to the wall thickness probably does not hold at those temperatures. The second possibility $1 \mathrm{~s}$ enhancod by the fact that tho diffusion rates determined at vaxious times during the run and at essentialiy the same temperatures were different. This would indicate that changos rero taking place in the motal of the reactor 1 tself. Thls has also beon shown by photomlerographs of sections of an old reactor.

Because of this loss, no very accurato ealculation of tho composition of the solid phase could be made. Tyro methods adopted to get as close an epprozimation as possiblo. A.) Whonever all of the hydride could bo decomposed, the amount of hydrogen in the gas phase was calculated. This was compared with the amount present after the provious decomposition. The amount $10 \mathrm{~s}^{\mathrm{t}}$ was then distributed overs the time the reactor was above $400^{\circ} \mathrm{C}$. B.) When, for long periods of time; it mas impossible to decompose all the solid, tho total amount of hydro. gen present was calculated in the following manner. At a time when none of the solid was decomposed, the total amount of gas 
Fas calculated by adding that associatod with tho solid of maximum hydrogers content to the amount in the gas phase. These values were compared with previous comparable values and the 10s3 distributed as before. The composition of the solid phaso was teken as 1.85 hydrogen atom to each magnesium atom. This was a compromise between sevon caleulated compon sitions which ran from 1.76 to 1.96 .

One final problem should be briefly noted. Tinis is tine inaccuracy of the P-V-T rolationships for bydrogen which were used. The best avaliable values cover a range only to $327 \% \mathrm{C}$ and 100 atmosphores. The values which have been used have been obtained by extrapolation of the published data. Therefor 0 , thero may be further large errors in any calculations involving conditions more severo than $327^{\circ} \mathrm{C}$ and 100 atmospheros.

In the above manner, over 125 points have been taken. The temperature vs. the pessure wes plotted and the solld como position calculatod for each of these. Practically without exception, the value of tho prossure has beon a function solely of the tomperature, Indepondent of the composition. The handful of values which seemed to deviate were rechecked as closely as possible and the deviation vas not roproducible. This would indicato there are two solid phases throughout the range messured.

Due to the afficulty of meking accurate composition calculations, solld phases of very high or low hydrogen content were difficult to obtain. To study these areas the following procedure was adopted. Sufflclent hydrogen was added so that at the temperature under study tho solid would heve the maximum concentration of hydrogon posaible and there rould be prosent a few hundred pounds oxcers. The temperature was then maintalned constant and a plot of pressure vs. time made. If it is as sumed that the rate of diffusion at constent tomperature sec $^{\circ}$ maing the same or decreases slowly in a regular manner with docrease in internal pressure, then the first part of the graph should show a linear or slightly curved line with negative siopo. A silghtif curved IIno is actualiy found. In the two phase region, the curve should bo level at constant pressure. If al Lowance is mado for tho slight temperaturo fiuctuations actually prosent in the reactor, 1088 then $10 \mathrm{C}$, and the corres ponding fluctuations in the decomposition prossure of the solid, about 50 p.s.1., then the curve is indeod level. In betroen these two, a one solld phase region should appear as a third distinct portion of the Eraph. No such xogion is a jet discerno ible. Therofore, as tho single solid phase regions should appesi at the upper and lower limits of the hydrogen concentration range, it now appears that there is no such region in this system. 


\section{- Futiro Plane}

Another attempt is boing made to cut the rate of difrusion to a negligibio amounto This is boing tried by constructing anothor reactor with evon thicker wal1s. Both the body cavity and the neck have been drilied out of a $3 i n g$.le piec of $5^{\prime \prime} 0 . D_{0}, \# 347$ stainless steel rod, $7^{\text {I }}$ long. The dimenelons of the main cavity and tho nock are tho 8 ame as before. In this case, a plug has boen weldod into the botcom to elose the reactor. It will be filied with magnesiun and the inlet tube attechod by axc-wolding. After checking tho actual rate of diffusion, anothor run will be carsiod out. If the diffusion is actually small, compositions will be capable of much more accurate/calculation. If this run is successful and checks closely with the last one, another may or may not bo carried out. Finaliy. the magnesium-deuterium systom will be studied in the same manner. 
THIS PAGE

\section{WAS INTENTIONALLY}

LEFT BLANK 
